\title{
EMPLOYEE PERFORMANCE IN IMPLEMENTING COMPLETE SYSTEMATIC LAND REGISTRATION: A STUDY ON THE OFFICE OF AGRARIAN AFFAIRS AND SPATIAL PLANNING/NATIONAL LAND AGENCY OF KUPANG REGENCY, INDONESIA
}

\author{
Firmus Bulu Jimmy*, Gana Frans, Djaha Ajis Salim Adang \\ Master's Program in Administrative Sciences, Postgraduate Program, \\ University of Nusa Cendana Kupang, East Nusa Tenggara, Indonesia \\ *E-mail: jimmy.bulu@gmail.com
}

\begin{abstract}
This study aimed to describe and analyze employee performance in implementing Complete Systematic Land Registration (Program Pendaftaran Tanah Sistem Lengkap -PTSL) in the Office of Agrarian Affairs and Spatial Planning/National Land Agency of Kupang Regency. In detail, the present study aimed to describe and analyze the quality, quantity, effectiveness, and timeliness of the land registration using a descriptive qualitative approach. The subject of the study was the Office of Agrarian Affairs and Spatial Planning/National Land Agency of Kupang Regency because it was in charge of the land registration program. Respondents were chosen purposively. The focus of the study was employee performance, with (1) quality, (2) quantity, (3) effectiveness, and (4) timeliness as the sub-focus. Findings suggested the followings. First, employee's skills and ability in understanding the objectives and guidelines of the program as well as the information and technology significantly affected their performance. Second, employee quantity significantly affected performancethe higher the quantity, the better the performance and vice versa. Third, timeliness significantly affected performance. Fourth, effectiveness significantly affected performancethe higher the effectiveness, the better the performance and vice versa.
\end{abstract}

\section{KEY WORDS}

Performance, employee, implementation, program, land registration.

Kupang Regency is one of the supporting regencies for the provincial capital. It has the largest administrative area in East Nusa Tenggara, with a total area of $5,298.13 \mathrm{~km}^{2}$ consisted of 3,278.25 $\mathrm{km}^{2}$ ocean, 288,397 ha forest, and 95,856.19 ha land (Central Bureau of Statistics Kupang Regency, 2019). The detailed information is presented in the following table:

Table 1 - Comparison of Total Area and Land Registered in Kupang Regency

\begin{tabular}{|l|l|l|l|}
\hline Category & $\mathrm{Km}^{2}$ & $\mathrm{Ha}$ & Meter \\
\hline Total area $\left(\mathrm{km}^{2}\right)$ & $5,298.13$ & $529,813.00$ & $5,298,230,000.00$ \\
\hline Ocean & $3,278.25$ & $327,825.00$ & $3,278,250,000.00$ \\
\hline Forest $(2019)$ & $2,883.97$ & $288,397.00$ & $2,883,970,000.00$ \\
\hline Land $\left(\mathrm{km}^{2}\right)$ & 958,561 & $95,856.19$ & $958,561,900.00$ \\
\hline Registered land & 626,025 & $62,602.598$ & $626,025,979.00$ \\
\hline Unregistered land & 332,536 & $33,253.59$ & $332,535,921.00$ \\
\hline Percentage of registered land & 65.31 & 65.31 & 65.31 \\
\hline
\end{tabular}

Source: Data Analysis (2019)ю

The Office of Agrarian Affairs and Spatial Planning/National Land Agency of Kupang Regency (Kantor Kementerian Agraria dan Tata Ruang/Badan Pertanahan Nasional ATR/BPN) is in charge of collecting data and issuing a land certificate. It has made many achievements throughout the years, including achieving targets of land registration. The office has issued 100,813 land certificates from $626,025.979 \mathrm{~m}^{2}(65.31 \%)$ of the total land area of Kupang Regency. 
ATR/BPN Kupang Regency keeps improving its services. Every inch of land must have legal certainty to minimize potential conflicts. Unfortunately, not all people understand how to register land and how their applications for land certificates are processed. The community has the right and opportunity to have legal guarantees for their land through a complete systematic registration process. The data on the achievement of the Complete Systematic Land Registration (Pendaftaran Tanah Sistematis Lengkap - PTSL) in Kupang Regency are as follows:

Table 2 - Targets and Achievement in Land Registration and Certification through PTSL

\begin{tabular}{|c|c|c|c|c|c|}
\hline \multirow[b]{2}{*}{ Year } & \multicolumn{4}{|c|}{ Total Area (within the calculation of certificate) } & \multirow[b]{2}{*}{ Note } \\
\hline & $\begin{array}{l}\text { National } \\
\text { Target }\end{array}$ & $\begin{array}{l}\text { Regency } \\
\text { Target }\end{array}$ & Achievement & Percentage & \\
\hline 2017 & 5 million & 10 thousand & 10 thousand & $100 \%$ & $\begin{array}{l}\text { With assistance from the East Nusa } \\
\text { Tenggara National Land Office }\end{array}$ \\
\hline 2018 & 7 million & 7 thousand & 7 thousand & $100 \%$ & $\begin{array}{l}\text { Done by the officials from the Kupang } \\
\text { Regency National Land Office }\end{array}$ \\
\hline 2019 & 9 million & 6 thousands & Ongoing & - & - \\
\hline Total & 21 million & 23 thousands & 17 thousand & $100 \%$ & \\
\hline
\end{tabular}

Source: Data Analysis (September 2019)ю

Table 2 shows that the national target increases by two million per year, and it applies to all regions in Indonesia, including Kupang Regency. Besides the achievement in PTSL, there are possibilities for failure in the process, one of which is related to the employees or officials of ATR/BPN. ATR/BPN of Kupang Regency can only appoint 17 officials to do the certification as mandated by the central government. These officials or employees are appointed based on a Letter of Statement issued by the head of ATR/BPN. The low number of employees and the high target of certificates to issue makes employees work very hard. The 2017 target could be achieved because the local officials of ATR/BPN Kupang regency were assisted by the officials from the provincial office. As such, we were interested in studying this situation.

This study aimed to describe and analyze employee performance in implementing Complete Systematic Land Registration (Program Pendaftaran Tanah Sistem Lengkap $P T S L)$ in the Office of Agrarian Affairs and Spatial Planning/National Land Agency of Kupang Regency. In detail, the present study aimed to describe and analyze the quality, quantity, effectiveness, and timeliness of the land registration using a descriptive qualitative approach. It is expected that the findings would be beneficial for the government as a reference in policymaking and for program implementers to improve the implementation of programs and policies. The study would also become a source of knowledge and information for further studies and interested parties.

\section{LITERATURE REVIEW}

Work performance refers to the results or outputs of a particular job function or certain activity in a certain period of time (Gomes, 1995). Performance measurement is a way to measure individual contributions to the organization (Gomes, 1995). Employee performance is positioned as the dependent variable in empirical studies because it is seen as a result or impact of organizational behavior or human resource practices, not as a cause or determinant.

Gomes (1995) further explained two criteria for measuring performance or employee performance: (1) result-based performance evaluation and (2) behavior-based performance evaluation. Result-based performance evaluation means measuring performance based on organizational goals achieved or measuring final results only. Organizational goals are set by management or workgroups, then employees are encouraged to achieve the goals, and their performance is assessed based on how far the employees have achieved the goals. This measurement criterion refers to Management By Objective (MBO). The advantage of 
this method is it helps to set clear and quantitatively measurable criteria and performance targets. However, the main weakness is that many jobs cannot be measured quantitatively in the practice of organizational life, so they are considered to ignore non-quantitative performance dimensions (Gomes, 1995).

Behavior-based performance emphasizes the means in achieving goals and not on the final results. Behavior-based performance tends to measure qualitative rather than quantitative aspects. It is generally subjective and assumes that employees can accurately describe effective performance for themselves and their co-workers (Gomes, 1995). The main weakness is that it is prone to measurement bias because performance is measured by perception. To overcome this,) suggest The use of instruments that measure the many aspects of specific behavior, such as innovative behavior, taking the initiative, level of selfpotential, time management, achievement of quantity and quality of work, self-ability to achieve goals, relationships with colleagues and customers, and knowledge of the company's products and competitors' products, can help overcome the weakness of behavior-based performance measurement and accommodate a very wide range of performance measures to obtain a comprehensive picture of job performance (Babin and Boles, 1998; Bono and Judge, 2003).

The quality of human resources determines an organization's performance in the organization. Performance has a broad meaning-it covers the results of work and the ongoing work process. According to Armstrong and Baron (1998), performance results from work with a strong relationship with the organization's strategic objectives, customer satisfaction, and contribution to the economy. An organization must monitor, assess and review the performance of human resources. The three things will help to determine whether employee performance is in line with the targets. If the target is not achieved, it is necessary to evaluate the employee performance.

Companies will usually use an assessment indicator in evaluating employee performance. Robbins (2006), in "Organizational Behavior Measurement of Individual Employee Performance," mentions five indicators to evaluate employee performance: quality, quantity, timeliness, effectiveness, and independence.

Quality is one of the main criteria that determine product selection for customers. Customer satisfaction will be achieved if the product quality meets their needs. Deming (1982) defines quality as a continuous improvement based on statistical tools with a bottomup process. Deming (1982) does not include the cost of customer dissatisfaction because according he thinks that costs cannot be measured. Deming's strategy is to look at processes to reduce variation since improving quality will reduce costs. He has a strong belief in empowering workers to solve problems, providing management with the right tools.

Meanwhile, according to Taguchi (1987), quality is a loss to society-a target deviation means a reduced quality function. On the other hand, the reduced quality will incur costs. Taguchi's (1987) strategy focuses on improving efficiency for repairs and cost considerations, particularly in the service industry.

Then, seen from the research problems, we argue that quality is an increase in the ability and skills of employees systematically according to the demands of growing science and technology.

Work quantity is a measure of how long an employee can work in one day; in other words, work quantity is all kinds of units of measure related to the amount of work expressed in numbers or other equivalent numbers (Mangkunegara, 2009). Furthermore, Chin \& Osborne (2008) argue that quantity is the number of questions.

Brotoharsojo and Wungu (2003) define quantity as any form of measurement unit related to the amount of work expressed in numbers or any units that can be matched with numbers. Wilson and Heyyel (1987) write that quantity of work is the amount of work carried out by an employee in a certain period. It can be seen from how employees use a certain time and speed to complete their tasks and responsibilities. The amount of work is the number of tasks that can be done. The use of time is the amount of time used in completing tasks and work. 
In this study, we define quantity as a number or amount. Thus, based on the research problem, quantity is the number of employees appointed by the Letter of Statement issued by the head of ATR/BPN to take care of the PTSL program.

Timeliness is the use of information by decision-makers before the information loses its decision-making capacity (Chairil and Ghozali, 2001 in Ukago, 2005). Timeliness is very important for information users-information must be timely, so it must reach main users before it spreads to others. Timely information means information must be submitted as early as possible so that it can be used to make economic decisions and avoid delays in making these decisions (Baridwan, 1997 in Tjiptono \& Anastasia, 2003).

We define timeliness as how far or well an activity is completed, or a result is produced, at the earliest time in coordination with other outputs and maximize the time available for other activities. More specifically, it can be said that completing a task is appropriate or earlier than the predetermined target time.

Sedarmayanti (2001) defines effectiveness as a measure that explains how far the target can be achieved. This understanding of effectiveness is more output-oriented while using inputs is less of a major concern. If efficiency is associated with effectiveness, even though there is an increase in effectiveness, it is not necessarily an increase in efficiency. Siagian (2001) defines effectiveness as utilizing resources, facilities, and infrastructure in a certain amount that is consciously determined beforehand to produce a number of goods and services for the activities carried out.

Effectiveness, in this case, shows success in terms of whether or not the targets have been achieved. If the results of the activity are close to the target, it means the higher the effectiveness.

Land registration comes from the word cadastre (kadaster in Dutch), a technical term for a record, indicating the area, value, and ownership of a plot of land (Parlindungan, 1999). This word comes from the Latin word capistratum, a register or capita or unit for the Roman land tax (Capotatio Terrens). In a strict sense, a cadastre is a record of land, the value of the land, and the holder of its rights for tax purposes. Thus, the cadastre is an appropriate tool in providing this description and a continuous recording of land rights.

Land registration, according to Article 1 of Government Regulation Number 24 of 1997 on Land Registration, refers to a series of activities done on an ongoing and regular basis by the government, including collecting, managing, recording, presenting, and maintaining physical and judicial data in the forms of maps and lists of land parcels and flats, including the issuance of certificates as proof of rights for land parcels and as ownership rights for flat units and certain rights attached to them.

Thus, the elements of land registration based on the above description are as follow:

1. A series of activities - the activities include collecting physical and judicial land data;

2. A certain office-land registration is managed by a special office known as Badan Pertanahan Nasional (BPN) or the National Land Agency;

3. On an ongoing and regular basis-the process is based on legal regulations and is done until citizens get the land certificate they need;

4. Land data - the first data from land registration are the physical and judicial data. The physical data include land location, borders, building areas, and plants living on the land. The judicial data explain the rights of ownership, including the names of owners;

5. An area-it covers specific areas within an administrative unit of the Republic of Indonesia;

6. Certain lands—related to the object of land registration;

7. Evidence-there is proof of ownership in the form of a certificate.

Thus, land registration is a series of activities carried out by the government continuously and regularly regarding certain lands in certain areas by collecting certain information, processing, recording, and presenting the data for the benefit of the people to guarantee legal certainty of the land parcel, including the issuance of evidence and its maintenance. 
The government has targets to serve and provide 126 million certificates for uncertified land. However, until 2015, only 46 million land certificates have been issued or one-third of the target. BPN can only issue 500 thousand certificates annually. Under the current capacity of BPN, the government's target will be completed in 160 years. One of the causes is the lack of land surveyors in all regions. As such, BPN hired more land surveyors according to its needs. BPN also conducted a land registration acceleration program through the Complete Systematic Land Registration (Program Pendaftaran Tanah Sistem Lengkap PTSL). The result of the 2017 PTSL was a tenfold capacity of land certificate issuanceBPN could issue 5 million certificates in 2017. The 2018 PTSL had been successful in distributing 9 million certificates. It was targeted that another 9 million certificates could be distributed in 2019.

Kupang Regency targeted distributing 10,000 land certificates through PTSL in 2017 and 7,000 certificates in 2018. Since the regional BPN of Kupang only had eight (8) employees as land surveyors, the target was challenging.

\section{RESEARCH FRAMEWORK}

Companies will always conduct a performance appraisal on their employees if they want to develop. It aims to measure the capacity and ability of employees. In evaluating the performance of employees, companies usually use an assessment indicator.

We employed Robbins' theory (2006) in this study. Robins proposed five indicators of individual employee performance measurement: quality, quantity, timeliness, effectiveness, and independence. Thus, we first looked at the previous descriptions presented in the following framework in compiling a conceptual framework.

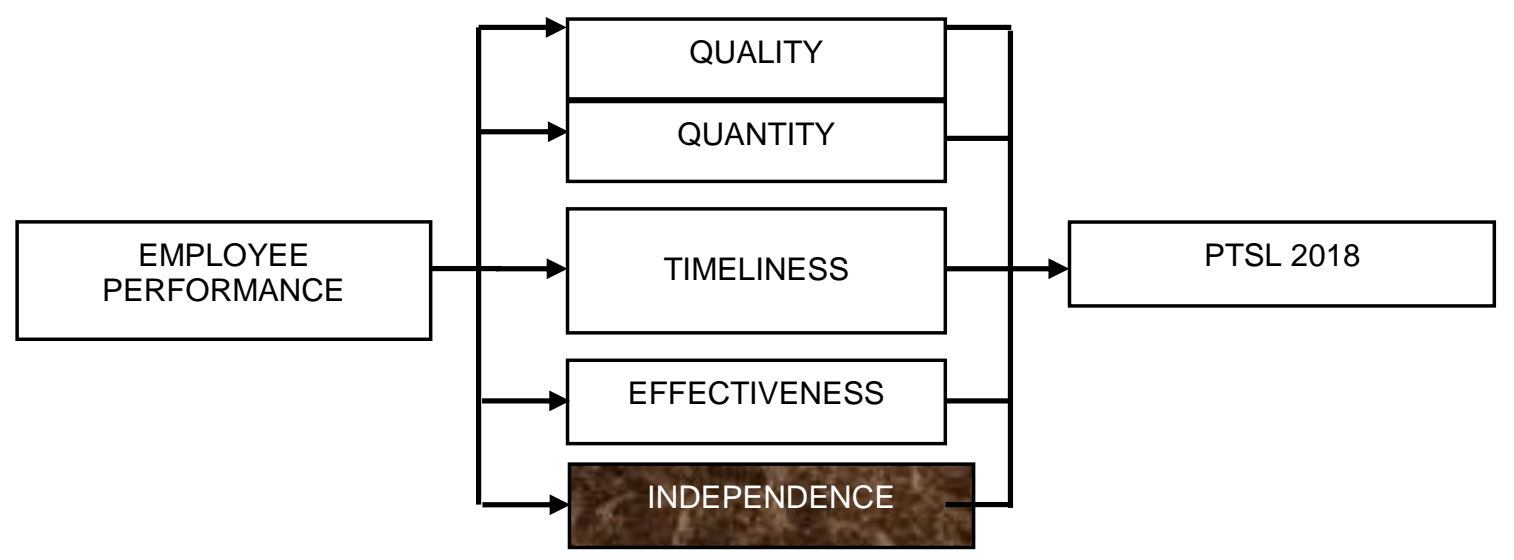

Figure 1 - Research Framework

This study employed four out of five indicators proposed by Robins (2006): quality, quantity, timeliness, and effectiveness. We believed that these four indicators would be enough to answer the research problems.

\section{METHODS OF RESEARCH}

This study was qualitative descriptive. The study site was the regional ATR/BPN office of Kupang Regency because the office is in charge of land registration and PTSL. Informants were chosen purposively. The focus was on employee performance with four sub-focus: (1) quality, (2) quantity, (3) timeliness, and (4) effectiveness. Data came from primary and secondary sources. Data were collected through interviews, documentation, and observations. Data analysis adopted the method by Miles and Huberman: data reduction, display, and verification. Triangulation was employed to check data validity. 


\section{RESULTS AND DISCUSSION}

Government institutions must adapt to the environment and developments and continue to make changes. Every organization generally expects employees to carry out tasks with quality results, in good quantity, and completed in a timely and effective manner. Human resources must have the competitiveness to produce good public services following the needs of the community. The supporting factors in the implementation of the task can be described as follows:

ATR/BPN officials shall identify the location, measure the area, ascertain boundaries, and do mapping as outlined in a map of land parcels. Therefore, employees capable of doing the given task are needed. Findings confirmed that the officials had been given the materials on legislation and technical guidelines before PTSL was implemented. The regulations shared included the 1945 Constitution Article 33 Paragraph 3, Law Number 5 of 1960 concerning Undang-Undang Pokok Agraria (UUPA) or Basic Agrarian Law Article 19 Paragraph 1 and 2, Government Regulation Number 24 of 1997 concerning Land Registration, PMNA 3 of 1997 concerning the Implementing Regulations of Government Regulation 24 of 1997, Regulation of the Minister of Agrarian Affairs and Spatial Planning (the Head of BPN) Number 6 of 2018 concerning PTSL and Technical Guidelines of 2018 Number 1/juknis/1/2018.

Findings confirmed that PTSL had been done following the technical guidelines. The guidelines include (1) preparing work maps based on basic registration maps; (2) preparing K4 data to record in KKP; (3) preparing measurement drawing; (4) conducting measurement; (5) mapping; (6) making field maps; (7) making land lists; and (8) issuing a letter of measurement. Findings confirmed that the ATR/BPN officials had mastered the needed skills well. They had a high quality of work and understood the technical guidelines.

The land is vital for most Indonesian people, whose society and economy are an agrarian structure. In this case, the ATR/BPN officials had met the community's expectations related to land ownership rights. Findings showed that there was an acceleration in the process of land registration, especially the free registrations. In other words, PTSL accelerated the land registration process in Indonesia. Findings also confirmed the people wanted legal certainty over their land. Many lands have unclear ownership status because they are inherited lands that have not been divided by to the next generation or customary lands whose distribution is still unclear. As such, various parties often claim such lands that the certificate cannot be issued.

In processing judicial and/or physical data, the officials or employees used data processing facilities, such as computers, printers, and the internet. All of the facilities were used to support the National Land Agency Computerization (Komputerisasi Kantor Pertnahan - KKP). In the implementation of PTSL, employees had to master the applications used in their work. Measurement is important, but a lack of mastery of knowledge in its application can also be fatal. However, the officials of ATR/BPN Kupang Regency had mastered measuring instruments to do their work well.

The achievement of organizational goals refers to realizing organizational programs or execution of the routine, general, and development tasks. Achievement means that humans essentially can excel above others. This ability can be reached if employees have high education, sufficient experience, a good mentality, and good morals. In this case, various regulations as the legal umbrella for PTSL have been issued, coordination between agencies has been built, and various breakthroughs have been made. However, many obstacles are found during PTSL implementation-because it focused on quantity and ignored quality.

Findings confirmed that PTSL implementation had followed the target number of measured land. Each village had a target number of measured land and certificates. Evaluation would be directly done if a village could not meet the target and be offered assistance from other villages that had finished their targets. Not all villages could meet the initial targets, but all parties worked hard to achieve the targets. As such, the ATR/BPN 
office could meet its organizational targets. However, some PTSL programs had not been completed because of a lack of officials.

Every organization expects to achieve all its targets, including ATR/BPN, to achieve the PTSL targets. If ATR/BPN fails to achieve its targets, it is necessary to collaborate with local governments, village governments, the armed forces, agencies, and communities. Findings confirmed that collaboration had been done in many areas, yet some areas did not seem to practice collaboration.

The government has been implementing a policy to improve service related to land registration, with massive land certification in all regions across Indonesia through PTSL, through Undang-Undang Pokok Agraria (UUPA), or Basic Agrarian Law and all its derivative regulations. PTSL aims to give all citizens a chance to have their land certificates at such a low price, especially for low-income groups. This program aims at providing legal certainty to land rights holders. Some challenges, however, arose in its implementation.

Work quantity is a measure of how long an employee can work in one day (Mangkunegara, 2009). For PTSL, it means how many land areas could be physically measured by one officer a day and how many judicial reports of land were collected a day. This indicator is related to the third parties of external parties. There had been a miscommunication with these external parties or the community due to their low understanding of PTSL, so the officials of ATR/BPN Kupang Regency had to explain the objectives of PTSL to the community. PTSL objectives must be delivered using simple words or using the native language of the community because many of them cannot speak Indonesian fluently so that the community can understand better.

PTSL is the first complete systematic land registration implemented throughout Indonesia. PTSL is done on a village basis or an administrative unit equal to a village, covering the collection and issuance of physical and judicial data of one or more land parcels for certification. PTSL acceleration is regulated in Article 3 Paragraph (3) of the Regulation of the Minister of Agrarian Affairs and Spatial Planning/National Land Agency Number 1 of 2017. PTSL shall follow the target given by the government. Findings showed that each ATR/BPN is given a deadline to complete the target on September 31 each year. ATR/BPN of Kupang Regency completed its target in early September 2018. However, the short time for target completion sometimes reduced the quality of physical and judicial data. Land officials found it hard to complete the target because they had to divide the time between working on the judicial data for routine collection and the judicial data for PTSL. The officials had to stay overnight in the village where they did the land measurement. They also had to spend their weekends and holidays to finish the task. The lack of officials was one of the main causes for delayed PTSL land certification.

PTSL is an acceleration in land registration and certification. The National Land Agency is in charge of PTSL, and it assigns each Regional Land Agency to implement PTSL. PTSL regulations aim to provide legal certainty for the process. PTSL requires government support that includes the National Land Agency and all Regional Land Agencies. There have been innovations done in PTSL implementation. First, maps, documents, and drawings have been digitized. Second, the "Sentuh Tanahku" application helps landowners plot their land. Third, KKP has been beneficial for record entries, including documents, maps, certificate printing, recording, and reporting. Fourth, using the latest and most sophisticated measuring tools has been a great way to overcome the lack of officials and accelerate the measurement process. Fifth, there has been the auto-entry application that fastens the process of document entries. Sixth, the announcement has been made faster, from 60 days to 14 days. Seventh, document entries are done using ID numbers (ATR/BPN cooperates with the Ministry of Home Affairs). Eighth, ATR/BPN works with the Ministry of Forestry and Environment related to forest area boundaries, rivers, beaches, etc. Ninth, ATR/BPN recruits more employees to work as ASK, SKB, and KJSKB to take and record physical data for PTSL all across Indonesia.

PTSL targets have been seen as too ambitious, and many parties consider the targets as having the political interests of certain people. PTSL is different from the previous programs because the president supervises, evaluates, and even directly intervenes in the 
process. The Ministry perfects the written regulations and legal bases, improves human resource quality, increases quality and quantity of facilities and infrastructure to ensure legal certainty and legal protection for the PTSL program, reduces disputes, and accelerates the program itself.

Findings showed there were concerns that Ministerial Regulation Number 35 of 2016 jo the Regulation of the Minister of Agrarian and Spatial Planning (Head of BPN) Number 1 of 2017 concerning PTSL cannot guarantee legal protection for the certificate issuance because it is following the Government Regulation Number 24 of 1997-the later regulation is hierarchically higher. One of the problems is the length of time for the announcement and examination of judicial data that no longer go through the adjudication process (inspection trial in the field) - it is increasing the time for PTSL.

PTSL is an acceleration for land registration. Effectiveness is a benchmark for comparing the process with the goals and objectives achieved. Employees in the organization are required to work earnestly and diligently, following the procedures and work plans. Employees also have to make the best use of working time so that objectives can be achieved well and mistakes, shall there be any, can be reduced to a minimum. Findings suggested that the number of PTSL program implementers was sufficient to complete the work according to the targets. The officials could finish their work well, although they had to finish measuring 8,000 land parcels and 7,000 certificates and be responsible for completing 1,000 land parcels in the land redistribution program. They were also responsible for routine activities of issuing land certificates with around 20,000 applications per year. It confirmed that official shortage was not one of the inhibiting factors of PTSL.

Kupang Regency is hilly with a slope of up to $45^{\circ}$, yet part of it is lowland and coastal areas. Therefore, PTSL took a longer time to finish. However, if the officials worked extra, including working on the weekends, staying overnight in the village to do land measurement, and using suitable applications, PTSL targets could be met. Thus, it can be stated that the effectiveness of employee work is a series of activities carried out by employees to work as planned accurately in terms of quality, quantity, and timeliness. In this case, the Kupang Regency ATR/BTN has been able to implement it quite effectively.

\section{CONCLUSION}

Based on the findings and discussion, the following conclusions are presented:

The ability and quality of human resources in understanding progams, technical guidelines, technology, communication, and information significantly affected work quality. The better the work quality, the better their performance will be and vice versa. Findings suggested good performance of the ATR/BPN officials. However, improvement is needed related to the educational background (the educational background does not match the job), late work completion because it involved the third party (the community), and the inability to catch up with technological advancements.

Employee quantity significantly affected performance-the higher the work quantity, the higher the level of employee performance and vice versa. Findings showed good performance. However, some improvements need to be made, such as the ability of officials to communicate with the third party (the community), the ability to cooperate with the law enforcement officials (the police, prosecutors, and courts), the ability to meet daily measurement target, the ability in recording and keeping records to avoid losing the judicial documents, etc.

Timeliness significantly and positively affected employee performance. Findings suggested that employees were timely. Nevertheless, some improvements shall be made. Respondents asked for more time to complete the judicial document, so it took a long time for officials to complete their job.

Effectiveness significantly affected performance-the higher the effectiveness, the better the performance and vice versa.

\section{SUGGESTIONS}


Based on the conclusions, the following suggestions are given:

1. The ATR/BPN officials must do their best in implementing PTSL so the community can get legal certainty;

2. The ATR/BPN officials must put quality before quantity in implementing PTSL so that the community can get legal certainty. If there are mistakes in the procedure and stages of PTSL, the officials are responsible for those mistakes, not the office;

3. There must be good legal protection for the ATR/BPN officials to do their work well without fearing that they will be charged with criminal acts when they make mistakes with the SOP;

4. The findings can be used to increase knowledge, insight, and additional information related to land registration.

\section{REFERENCES}

1. Gomes, Faustino Cardoso. 1995. Manajemen Sumber Daya Manusia. Yogyakarta: Andi Offset.

2. Babin, B.J. \& J.S. Boles (1998), "Employee behavior in a service environment: A model and test of potential differences between men and women", Journal of Marketing, Vol. 62, hal. 77-91.

3. Bono, J.E., \& Judge, T.A. (2003). Self - Concordance at Work: Toward Understanding the Motivational Effects of Transformational Leaders. Academy of Management Journal, Vol. 46, No 5, $554-571$.

4. Amstrong, M dan Baron, A. (1998). Performance management handbook. IPM, London.

5. Robbins, P. Stephen. (2006). Perilaku Organisasi. Edisi Sepuluh. Diterjemahkan oleh: Drs. Benyamin Molan. Erlangga, Jakarta.

6. Deming, W. Edwards. 1982. Guide to Quality Control. Cambridge: Massachusetts Institute Of Technology.

7. Taguchi, G., (1987), System of Experimental Design, (Vol. 1-2), UNIPUB/Kraus International Publication, N.Y.: White Plains.

8. Mangkunegara, A.A. Anwar Prabu. 2009. Manajemen sumber daya manusia. Remaja Rosdakarya. Bandung.

9. Chin, C., and Osberne, J., (2008), Students' Question: A PotentialResource For Teaching and Learning Science. Studies in Science Education. 44(1). 1-39.

10. Brotoharsojo, Hartanto \& Wungu, Jiwo, 2003, Tingkatkan Kinerja Perusahaan dengan Merit System, PT. Rajagrafindo Persada, Jakarta.

11. Willson and Heyyel. 1987. Hand Book of Modern Office Management and Administration Service. Mc Graw Hill Inc. New Jersey.

12. Ukago, K., I. Ghozali, dan Sugiyono, 2005. "Faktor-Faktor yang Berpengaruh Terhadap Ketepatan Waktu Pelaporan Keuangan: Bukti Empiris Emiten di Bursa Efek Jakarta". Jurnal Maksi, Vol.5, No.1:13-33.

13. Tjiptono, Fandy dan Anastasia Diana. (2003). Total Quality Management. Edisi Revisi. Yogyakarta: Andi Offset.

14. Sedarmayanti. 2001. Sumber Daya Manusia dan Produktivitas Kerja. Bandung: Mandar Maju.

15. Siagian, Sondang P. 2001, "Manajemen Sumber Daya Manusia”, Bumi Aksara, Jakarta.

16. Parlindungan, A.P. 1999.Pendaftaran Tanah Di Indonesia.Bandung . MandarMaju.

17. Miles, Mattew B dan Amichael Huberman. 2007. Analisis Data Kualitatif Buku Sumber tentang Metode-Metode Baru. Terjemahan Tjetjep Rohendi Rohisi. Jakarta: Universitas Indonesia. 